\title{
GEOSTRATEGIC HYPOTHESES FOR INTEGRATION AND DISINTEGRATION IN THE FUTURE OF THE REPUBLIC OF MACEDONIA
}

DOI: http://dx.doi.org/10.18509/GBP.2015.40

UDC: $316.4 .063 .24 / .3(497.7)$

\author{
Prof. Dr. Sc. Dimitrina Naneva \\ SU “St. Kliment Ohridski”, Bulgaria
}

\begin{abstract}
Geostrategy, as an application direction of the geopolitics uses different analysis criteria, among which leading is the national interest. Its essence is demonstrated in two basic directions: 1/foreign political and internally political. Actually, the research mechanisms of geostrategy are also mechanisms for analysis of the regional policy and security [1]. Geostrategy uses as a starting point the formulated by geopolitics fundamental laws. Because of this, the modern geostrategic approach is a complex "formula" for management solutions of conflicts with zonal or key character. The accent is put mainly on the "conglomerate" of historical and legal evaluations, traditions and doctrines, ethnic and confessional political relations, as well as ruling ideological concepts. Such "conglomerates" today are the Atlantism and the Europeism.

In the second decade of the 21 st century the geostrategic analysis requires rethinking of their ideological "formulae".
\end{abstract}

\section{ATLANTISM VS EUROPEISM}

The division is needed because of today's extremely dynamical balance in the international, and particularly European environment, and finding a new measure of stability that emanates security. Interests vs values, society vs community, federation vs unitary state, the West vs the "West of the East...", - these are just part of the dilemmas, which seek solution and have effect over the management of modern conflicts. [2]

200 years after the French revolution -1789, the Cold war ends. This event affects mainly the "Western part of the Eastern hemisphere", i.e. Europe and the EU. It brings about a kind of "earthquake" in the set by the winners of the World War II status quo. The "Eastern block" is falling apart and the regional sentencing of the totalitarian communist regimes in Europe is becoming a decree. The "status quo" returns the legitimacy of the principles, introduced in Europe during 1919 thanks to the Versailles system of peacetreaties; a key moment amongst them is the "self-definition of the peoples".

The "Paris Charter for New Europe" - November 1990, Paris, is the document that declares this turning point. The Charter protects the territorial integrity of the 35 -signee countries, including ex-Yugoslavia and ex-USSR, dismisses the opportunity for the use of force in order to solve conflicts. Cooperation and political dialogue are evaluated as rational strategy and mechanism for the building of New Europe, and later - the EuroAtlantic community [3].

25 years later, the political realities especially within the Balkan Peninsula, are different from the ones envisaged in the Charter. Yugoslavia is non-existent, 6th republic in exSFRY-Republic of Macedonia, has a status of associated member of the EU, but also a veto from NATO for entering the pact. Republic of Macedonia has some unsolved "neighbour" issues: with Greece - because of the name, and with Bulgaria - because of the historic-geographical and cultural identity of the larger part of the population in 
"Vardar Banovina" until 1944. After the signing of the Ohrid peace-treaty - 2001, and the partial international recognition of the Republic of Kosovo-2009, the issues with the historical law and the practices for application of a double standard in the international relations do not find solutions in the Euro-Atlantic community. The prolongation of the international conflicts, however, destabilises the "conglomerates": "Atlantism" and "Europeism", as well as the regional architectonic. Main field of the conflict between them is the interpretation of the religious and ethnic identities in the context of the European spiritual and cultural heritage.

\section{PREQUEL}

The introduction of the Atlantic construct "political nation", i.e. "people", understood as an "aggregation of individuals with equivalent political and civil status" in Europe, with no regards to ethnic characteristics, starts in France in 1789. The example is set by the foundation of the American nation, in accordance with the US Constitution - 1776. In France at that time the "people" are 3rd estate. "Political nation" is reached through enforcing social unification of the historical French community. The creation of a national Unitarian state with Republican form of state governance, secularisation of the Church from the State, introduction of obligatory state school education on set standards learning French language and history of the revolution - 1789, are all part of the tools of the process. The "truce" between "people" and "nation" in Europe then follows the political vision that the people that have earned the political power, turn to nation [4]. This is the first attempt at integrating the social aggregates at the both sides of the Atlantic on the basis of a unitary criterion.

The two projects that were formed - American and European - differ by the way of their implementation and by their starting proceedings. The American "project" is based on the voluntary and personal interest of the citizen - non-violence is a basic trait. The European project is born in violence, civil wars, revolutions, dictatorships, nihilism, smoldering conflicts, and political instability.

In accordance with the European cultural tradition in the beginning of the 20th century, the French MP Maurice Barres adds to the project the categories "titular nation", "national minority", and "ethnic diaspora".

The 14 paragraphs of the American president W. Wilson from January 1918 protect the project "political nation". Paragraph 6 of them - "self-definition of the peoples" guarantees the American support of the right to a free political choice of the peoples of Russia, i.e. justifies the goals of the October revolution - 1917 in Russia. That is the beginning of the cycle of the class, supranational, i.e. international ideological "reconstruction" of the European nations during the 20th century from the point of view of the now 4th estate, i.e. the proletariat. The applied form of state structure is the federation, and the new context creates the European precedents "Macedonian nation", "Soviet people", "Yugoslavic people", socialistic German nation, ex-USSR, ex-SFRY...

\section{MODERNITY}

After 1990 the EU doesn't succeed in identifying its own approach towards the historical heritage in the field of the ethno-religious problematic. Because of this it introduces a standard, inherent to the communities in Northern America. We talk about the "individually orientated multiculturalism". In the Balkan Peninsula the Ohrid Treaty is the first attempt at "European management" in this context. After the plebiscites, imposed on Germany after 1919, the treaty introduces quote - "20\%" for recognition of "ethnic 
difference" and identity on a "group" level, i.e. the existence of Albanian ethnic group as a part of the aggregation of citizens, sovereign to Republic of Macedonia. From this moment on, the further development of this state is directed at two options: disintegrational and integrational. They develop in an external environment, which is participant to the "game" and part of it is the already once "prized" Albanian nation /"Kosovo"/ with the support of the Euro-Atlantic co-society.

The first option is relevant to the European context. The precedent "Kosovo" - 2009 in practice ruled the existence of Albanian nation for now in two countries. The introduction of $20 \%$ threshold in Republic of Macedonia for "ethnic co-appurtenance" of a minority group is not a sufficient condition as per the present moment for its territorial secession. The Ohrid Treaty confirms only the multiethnic character of the civil nation, and does not sanction that Republic of Macedonia is a "multinational state"[5]. The federalisation or cantonisation of the state is not a foretold event in this case. The process passes through the passing of a new fundamental act, including the carrying out of a referendum for legitimising of a new federal state construction, in which all Macedonian citizens of age should participate. The federal type of state, introduced by the Dayton agreement - 1995 in Bosnia and Herzegovina is also a possible scenario. But for the limited territorial, demographic and material resources of Republic of Macedonia, this option is disadvantageous. That is why the two factors - the acceptance of the Atlantism or the Europeism in the Balkan Peninsula, and the "price" of the administrative "reconstruction", are fundamental for the future of this option. Its principally positive trait is the moving away from the "Slavonic rainbow" in its historic-political projections - the Pan Slavism of the Russian empire, which further becomes a class-based, cominternal Balkan project for federation and the American idea - 1919, for the creation of a state of the Southern Slavs of the Peninsula. The option has Eurocentric character.

The integrational option is instrumental. It assumes the clearance of all ethnic accents with European flavour, still existent in the preamble of the Republic of Macedonia's Constitution - 1991, after its amendments. The Atlantic standard for "political nation" means neoliberal territory-centred society, which guarantees the fundamental rights and freedoms of the separate citizen, and not of an ethnic group. This option assumes the use of "state" language, refusal to the existence of "national minorities" in neighbouring countries, secularisation of all religions. A major factor for the integrity of the neoliberal civil society is the instrumental interest for a durable procedural consensus of the established representative democracy and high level of trust in the established institutions. The political communication shall, however, obligatory pass through the introduction of acts for decommunisation in accordance with the EU positions. This is a condition for recovery of the transparency of the community dialogue and wiping out of the ideological and other dependencies in Republic of Macedonia after 1945. "The reciprocal altruism" is essential to the administratively social relation between civil society and administrative apparatus; it is guarantee for cooperative behaviour and articulation of management strategies, based on teamwork in the name of the utilitarian rationalism. In foreignpolitical plan the "equidistance from the neighbours" becomes a naturally durable position and does not emanate conflicting messages. 


\section{REFERENCES:}

[1] Rousev, M., A. Avdzhiev, Interdisciplinary Status and Spatial Essence of Geostrategy. Yearbook of the Sofia University, Bulgaria, vol. 105, pp 235-251, 2013.

[2] Citati, D., Why Europe Is Not Part of the West? Geopolitics, Bulgaria, vol. 5, pp 166$176,2014$.

[3] Charter of Paris for a New Europe. France, pp 3-14, 1990.

[4] Sieyès, A.E.J. What Is the Third Estate?, Bulgaria, pp 8-94, 2004.

[5] Slaveski, St., O.Bakreski, Zl., Nikoloski, The Macedonian Model for Solution of the Ethnic Conflicts, Geopolitics, Bulgaria, vol.2, pp 23-34, 2012. 